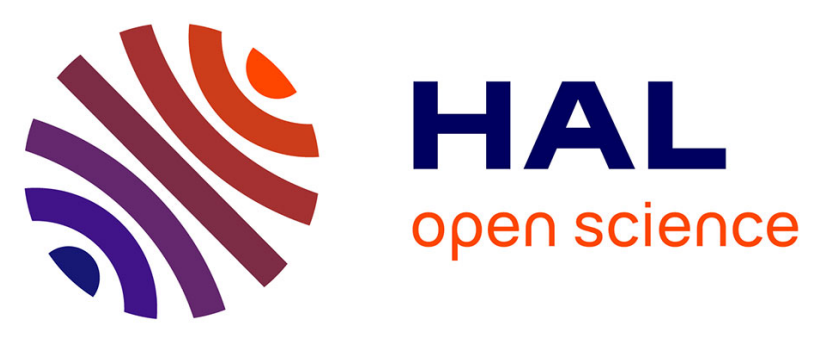

\title{
Temperature Phased Anaerobic Digestion (TPAD) of Organic Fraction of Municipal Solid Waste (OFMSW) and Digested Sludge (DS): effect of different hydrolysis conditions
}

Corrado Amodeo, Stephane Hattou, Pierre Buffière, Hassen Benbelkacem

\section{To cite this version:}

Corrado Amodeo, Stephane Hattou, Pierre Buffière, Hassen Benbelkacem. Temperature Phased Anaerobic Digestion (TPAD) of Organic Fraction of Municipal Solid Waste (OFMSW) and Digested Sludge (DS): effect of different hydrolysis conditions. Waste Management, 2021, 126, pp.21-29. 10.1016/j.wasman.2021.02.049 . hal-03172299

\author{
HAL Id: hal-03172299 \\ https://hal.science/hal-03172299
}

Submitted on 17 Mar 2021

HAL is a multi-disciplinary open access archive for the deposit and dissemination of scientific research documents, whether they are published or not. The documents may come from teaching and research institutions in France or abroad, or from public or private research centers.
L'archive ouverte pluridisciplinaire HAL, est destinée au dépôt et à la diffusion de documents scientifiques de niveau recherche, publiés ou non, émanant des établissements d'enseignement et de recherche français ou étrangers, des laboratoires publics ou privés. 


\title{
Temperature Phased Anaerobic Digestion (TPAD) of Organic Fraction of Municipal Solid Waste (OFMSW) and Digested Sludge (DS): effect of different hydrolysis conditions
}

\author{
Corrado Amodeo $^{1 *}$, Stephane Hattou ${ }^{2}$, Pierre Buffiere ${ }^{1}$, Hassen Benbelkacem ${ }^{1}$ \\ ${ }^{1}$ Univ Lyon, INSA Lyon, DEEP, EA7429, 69621 Villeurbanne, France \\ ${ }^{2}$ Arkolia Energies, 16 Rue des vergers, F34130 Mudaison, France \\ * Corresponding author: Corrado Amodeo (corrado.amodeo@insa-lyon.fr) \\ Waste Management, 126 (2021) 21-29 \\ DOI: https://doi.org/10.1016/j.wasman.2021.02.049
}

\begin{abstract}
Hydrolysis is the most critical stage in high solids Temperature Phased Anaerobic Digestion (TPAD). In this paper two different Organic Fraction of Municipal Solid Waste (OFMSW) types were tested in co-digestion with Digested Sludge (DS) at different temperatures: 37,55 and $65{ }^{\circ} \mathrm{C}$. Volatile fatty acids (VFAs), soluble chemical oxygen demand (CODs) and Biochemical Methane Production (BMP) were measured and calculated after $0,24,48$ and 72 h hydrolysis. The results showed that both the BMP and the methane production rate improved. A Solids Retention Time (SRT) of $72 \mathrm{~h}$ at a temperature of $55^{\circ} \mathrm{C}$ gave the best results: the reaction rate constant $\mathrm{k}$ was $0.34 \mathrm{~d}^{-1}$ and the BMP was $250 \mathrm{~mL}_{\mathrm{CH} 4} / \mathrm{g}_{\mathrm{MV}}$, which were $47 \%$ and $19 \%$ higher compared to the reference (0 h hydrolysis). The CODs and VFAs profiles during hydrolysis showed how OFMSW initial characteristics can affect the performance of temperature phased anaerobic digestion.
\end{abstract}

Keywords: High solids TPAD, OFMSW, Hydrolysis, Biochemical methane potential, Kinetics. 


\section{Introduction}

Anaerobic digestion (AD) is the biological decomposition of organic matter without oxygen. It is one of the most commonly used solutions for the biological treatment of different substrates such as agricultural waste, animal excreta and energy crops. It enables to reduce the environmental impact of organic waste and to produce a local energy source in the form of a methane-rich biogas. In Europe, the amount of biogas produced by AD has increased by $50 \%$ over the last 10 years (Scarlat et al., 2018).

Various technologies have been developed to improve the AD processes: Li et al. (2019) describe all of them for each phase of $\mathrm{AD}$ (hydrolysis, acidogenesis and methanogenesis). Among them, Temperature Phased Anaerobic Digestion reactors (TPAD) represent an interesting option to improve AD performance (Han et al., 1997; Harris and Dague, 1993; Kaiser and Dague, 1994; Oles et al., 1997). The TPAD process is generally a two-phase system where the first stage is dedicated to hydrolysis, solubilisation and acidogenesis and the second stage to methane production. Under these conditions it is possible to better manage operating parameters: high temperature $\left(41-70{ }^{\circ} \mathrm{C}\right)$ and low SRT (solids retention time: $24-96$ hours) for the first hydrolytic stage, low temperature $\left(30-40^{\circ} \mathrm{C}\right)$ and high SRT (20-30 days) for the second methanogenic stage.

One of the well-known problems of single-stage AD systems is the $\mathrm{pH}$ control when highly biodegradable organic matter is digested under high OLRs (Organic Loading Rates) (Prabhu et al., 2020; Sambo et al., 1995; Zhang et al., 2014). A low pH has a negative impact on the methanogenic activity (Bouallagui et al., 2009). TPAD systems enable to better manage $\mathrm{pH}$ and offer a better resistance to organic shock loadings (Chatterjee and Mazumder, 2019; Feng et al., 2020; Paudel et al., 2017). The understanding of the role of the hydrolytic stage is a key issue since hydrolysis is considered as the limiting step of the whole process (Appels et al., 2008). Reported studies agree with the idea that high temperatures (above $35^{\circ} \mathrm{C}$ ) improve hydrolysis rate. Leaving 
aside the experiments with temperatures higher than $80^{\circ} \mathrm{C}$, where thermal disintegration occurs (Bougrier et al., 2008), many works have focused on the optimisation of the hydrolytic stage. Two parameters are important: the temperature and the SRT (Lv et al., 2016). Ge et al., (2010) found a $25 \%$ increase in methane production with a thermophilic $\left(50^{\circ} \mathrm{C}-2\right.$ days $)-$ mesophilic $\left(35^{\circ} \mathrm{C}-14\right.$ days $)$ TPAD on primary sludge compared to a mesophilic $\left(35^{\circ} \mathrm{C}-2\right.$ days $)-$ mesophilic $\left(35^{\circ} \mathrm{C}-14\right.$ days $)$ TPAD reactor. The same research group found that on waste activated sludge the thermophilic $\left(65^{\circ} \mathrm{C}-2\right.$ days $)-$ mesophilic $\left(35^{\circ} \mathrm{C}-14\right.$ days $)$ TPAD achieved $48 \%$ volatile solids (VS) destruction in the first stage, $11 \%$ more than a mesophilic $\left(35^{\circ} \mathrm{C}-2\right.$ days $)-$ mesophilic $\left(35^{\circ} \mathrm{C}-14\right.$ days $)$ TPAD (Ge et al., 2011a). Considering waste activated sludge as substrate, Watts et al., (2006) achieved 46\% increase of VS reduction with a TPAD thermophilic (HRT 2 days $-60^{\circ} \mathrm{C}$ ) - mesophilic (HRT 15 days $-36^{\circ} \mathrm{C}$ ), compared to a single-stage mesophilic digester. The same effect was shown by Montañés Alonso et al. (2016) who tested TPAD on sewage sludge and sugar beet pulp leachate, with $40.5 \%$ more VS reduction.

The treatment of municipal solid waste (MSW) is an important challenge. The organic fraction of MSW (OFMSW) is a significant feedstock for AD with high biomethane potential (Chatterjee and Mazumder, 2016). The first attempt for co-digesting the OFMSW with primary sludge in a TPAD $\left(55^{\circ} / 35^{\circ}\right)$ gave promising results, with an improved VS destruction compared to a two-stage mesophilic control (Schmit and Ellis, 2001). TPAD gave successful results for the co-digestion of Food Waste (FW) and Paper Waste (PW) (Li et al., 2020; Qin et al., 2019, 2018; Romero-Güiza et al., 2014).

Recently, various works have been undertaken directly on AD of OFMSW. FernándezRodríguez et al., (2016) have tested a semi-continuous TPAD process for the digestion of the OFMSW from a mechanical-biological-treatment (MBT) plant. The results showed that the best configuration was the combination of a thermophilic stage (SRT 4 days $55-57^{\circ} \mathrm{C}$ ) and a mesophilic stage (SRT 10 days $-35-37^{\circ} \mathrm{C}$ ). They achieved $35-45 \%$ more 
methane production compared to a single mesophilic stage operating at similar SRT. Romero Aguilar et al. (2013) studied the hydrolytic stage of a TPAD for OFMSW in an anaerobic continuous stirred tank reactor (CSTR) operating under thermophilic conditions $\left(55^{\circ} \mathrm{C}\right)$ and different SRTs (between 1.5 and 15 days). The optimal SRT was 1.9 days for the hydrolytic stage in terms of solubilized organic matter and hydrogen production. Borowski (2015) used a TPAD process to treat a mixture of municipal sewage sludge with Hydromechanically Separated (HS) OFMSW. The best conditions (SRT temperature) were 1 day $-55^{\circ} \mathrm{C}$ for the hydrolytic stage and 14 days $-35^{\circ} \mathrm{C}$ for the methanogenic stage: the methane yield improve from $230 \mathrm{LCH}_{4} \mathrm{kgVs}^{-1}$ in a single-stage mesophilic process to $333 \mathrm{LCH}_{4} \mathrm{kgVs}^{-1}$. Kim et al. (2011) tested a temperature-phased anaerobic sequencing batch reactor (TPASBR) system for OFMSW digestion. They showed that a process with a thermophilic first stage enabled to treat higher organic loading rates than with a mesophilic first stage.

The aim of this work is to deepen the understanding of the role of the hydrolytic stage in a TPAD processes for the co-digestion of the OFMSW with digested sludge (DS). We have tested several temperatures $\left(37,55\right.$ and $\left.65^{\circ} \mathrm{C}\right)$ and different retention times $(24,48$ and $72 \mathrm{~h}$ ). The question was to know how this hydrolytic stage could have an effect on the overall digestion process: a better solubilisation, a higher amount of methane produced, or a higher rate of methane production. Considering the great variety of OFMSW, this study additionally focused on the substrate characteristics to understand which of them are the most relevant for TPAD plants.

This work was part of the first phase of a bigger project (the "COMETHA" project), which is a partnership of innovation between Syctom (Syndicat mixte Central de Traitement des Ordures Ménagères - Île-de-France) and SIAAP (Syndicat Interdépartemental pour l'Assainissement de l'Agglomération parisienne). These two structures are (respectively) in charge of waste management and wastewater treatment in 
the Paris region (France). The project aimed at developing innovative technical solutions for OFMSW and Digested Sludge (DS) co-digestion.

\section{Materials and methods}

\subsection{Hydrolysis tests: reactor, sampling and analyses}

To simulate a hydrolytic stage at laboratory scale, a stirred reactor (10L working volume) was setup (Supplementary Materials Figure S1). The temperature was controlled and regulated between 20 and $65^{\circ} \mathrm{C}$ by a water jacket. An anchor blade provided a uniform mixing at $17 \mathrm{rpm}$. The sampling was done through a drain valve (PN40) located at the bottom of the reactor.

At the beginning of each run, and after each sampling, the reactor was purged with $\mathrm{N}_{2}$ to ensure anaerobic conditions. Each test lasted $72 \mathrm{~h}$. In all the following steps $t_{0}$ refers to the sample without hydrolysis. Three other samples taken after 24,48 and $72 \mathrm{~h}$ are referred to as $t_{24}, t_{48}$ and $t_{72}$.

The weight of each sample was approximately $300 \mathrm{~g}$. For each sample, a raw fraction aliquot was kept aside, while the soluble fraction was extracted from another aliquot. The extraction procedure for the soluble fraction was the following: distilled water was added to the sample (weight ratio 10/1, water/TS) and the mixture was gently stirred for $2 \mathrm{~h}$ (rotating drum, 10rpm). The soluble fraction was then obtained after centrifugation (20 min, $5000 \mathrm{~g})$ and supernatant filtration $(0.45 \mu \mathrm{m})$ (Franco et al., 2019).

For the raw samples, Total and Volatile Solids (TS, VS) were measured and Biochemical Methane Potential (BMP) tests were carried out; for the soluble fraction: Chemical Oxygen Demand (CODs), Volatile fatty acids (VFAs), $\mathrm{pH}$ and BMP. A specific measurement of the COD of the particulate fraction was also performed for all samples taken at $\mathrm{t}_{0}$ (the procedure was derived from the ISO 14235:1998 standard). 


\subsection{Waste characterization and experimental runs}

Two different subcategories of OFMSW were considered: OFMSW_1 and OFMSW_2. Both came from the same full-scale MBT plant. The main differences were the sieve size (0-5 mm for OFMSW_1 and 0-10 mm for OFMSW_2) and the shipping time (shorter for OFMSW_2). Both were tested in co-digestion with two different DS: DS_1 (digested sludge) and DS_2 (digested dehydrated hydrolysed sludge). The characteristics of each substrate are given in Table 1. The use of digested sludge (from a WWTP) as a cosubstrate for AD may sound curious, since its methane potential is limited. However, it was selected within the framework of the COMETHA project in order to provide an adjustment of the incoming TS content rather than a major source of methane production. For each test, the reactor was filled with $10 \mathrm{~kg}$ of a mixture of OFMSW, DS and adapted inoculum. A mesophilic inoculum (from an OFMSW digester) was used for mesophilic tests at $37^{\circ} \mathrm{C}$, while a thermophilic inoculum (from another OFMSW digester) was used for the tests at 55 and $65^{\circ} \mathrm{C}$. The substrate (OFMSW + DS) to inoculum ratio was fixed at 3.4 VS/VS, and the final TS of the digestion medium was adjusted at $20 \%$ by addition of distilled water, as per necessity. Five experiments were undertaken to investigate respectively: the effects of hydrolysis temperature (exp. $1-2-3$ ); the effects of the type of OFMSW (exp. $4-5$ ); the effects of the type of DS (exp. $2-5$ ). The experimental conditions are shown in Table 2.

Table 1. Feedstock characteristics ( $\mathrm{RM}=\mathrm{Raw}$ Medium $)$.

\begin{tabular}{ccccc}
\hline & OFMSW_1 & OFMSW_2 & DS_1 & DS_2 \\
\hline TS (\%) & $46.1 \%$ & $47.2 \%$ & $8.9 \%$ & $9.6 \%$ \\
VS (\%) & $34.1 \%$ & $36.4 \%$ & $5.3 \%$ & $7.8 \%$ \\
BMP (mL m $\left.4_{4} \cdot \mathrm{g}_{\text {VS }}{ }^{-1}\right)$ & 340.5 & 322.7 & 246.2 & 243.9 \\
CODs $\left(\mathrm{g} / \mathrm{kg}_{\mathrm{RM}}\right)$ & 78.76 & 57.83 & 27.59 & 5.66 \\
VFA $(\mathrm{g} / \mathrm{kg}$ RM $)$ & 33.56 & 28.52 & 5.65 & 0.8 \\
\hline
\end{tabular}


Table 2. Experimental runs. Values are expressed in $\mathrm{kg}$ per batch of raw material. In bracket, values in $\mathrm{kg}$ of Volatile Solids.

\begin{tabular}{|c|c|c|c|c|c|c|c|}
\hline \multirow{2}{*}{ Exp. } & \multirow{2}{*}{$\mathrm{T}$} & \multicolumn{4}{|c|}{ Substrate } & \multicolumn{2}{|c|}{ Inoculum } \\
\hline & & OFMSW_1 & OFMSW_2 & DS_1 & DS_2 & Mesophilic & Thermophilic \\
\hline 1 & $37^{\circ} \mathrm{C}$ & - & $1.87(0.68)$ & - & $2.60(0.20)$ & $5.53(0.26)$ & - \\
\hline 2 & $55^{\circ} \mathrm{C}$ & - & $2.38(0.87)$ & - & $3.30(0.26)$ & - & $4.30(0.33)$ \\
\hline 3 & $65^{\circ} \mathrm{C}$ & - & $2.38(0.87)$ & - & $3.30(0.26)$ & - & $4.30(0.33)$ \\
\hline 4 & $55^{\circ} \mathrm{C}$ & $2.79(0.95)$ & - & $3.41(0.18)$ & - & - & $3.80(0.33)$ \\
\hline 5 & $55^{\circ} \mathrm{C}$ & - & $2.82(1.03)$ & $3.7(0.20)$ & - & - & $3.44(0.36)$ \\
\hline
\end{tabular}

\subsection{Analytical methods}

TS and VS were measured by mass difference after drying $\left(105^{\circ} \mathrm{C}, 48 \mathrm{~h}\right)$ and calcination $\left(550^{\circ} \mathrm{C}, 4 \mathrm{~h}\right)$ of the samples.. However, TS and VS may be underestimated because of an important losses of volatile compounds during the drying process (Kreuger et al., 2011). Therefore, TS and VS values were corrected according to the amount of VFA (Kreuger et al., 2011; Porter and Murray, 2001). Hach kits (15000 ppm range) were used to measure CODs; VFAs were measured by gas chromatography on a Shimadzu CG-FID using 2ethylbutyric acid as internal standard; $\mathrm{pH}$ was measured with Benchtop Meters Consort C3020.

The biogas production was measured continuously by a Ritter counter (type TG01 or MGC, depending on the flow rate) while the biogas composition was measured daily with an Agilent 3000 micro gas chromatograph, equipped with a thermal conductivity detector (GC-TCD). Molsieve 5A (14 m length; pore size: $5 \AA$ Å) and PoraPlotA (10 m length; $0.320 \mathrm{~mm}$ ID) columns were used as stationary phases for GC-TCD, with Argon and Helium as carrier gases, respectively. The micro-GC was calibrated for $\mathrm{H}_{2}, \mathrm{CO}_{2}, \mathrm{CH}_{4}, \mathrm{O}_{2}$ and $\mathrm{N}_{2}$. 
From these parameters, we calculated the amount of hydrolysed COD $\left(\mathrm{COD}_{\mathrm{H}}\right)$ (corresponding to the amount of particulate COD converted into soluble COD) with equation (1).

$$
C O D_{H}=C O D_{s}(t)+C O D_{\text {biogas }}(t)-C O D_{s}\left(t_{0}\right)
$$

Where $C O D_{s}(t)$ is the soluble COD at time t, $C O D_{s}\left(t_{0}\right)$ is the initial soluble COD, and $C O D_{\text {biogas }}(t)$ is the amount of COD that has been converted into biogas at time t. The latter was calculated from the methane and hydrogen production.

The amount of hydrolysed COD enables to calculate the hydrolytic yield as the fraction of particulate COD solubilized during the process (equation 2).

$$
Y_{H}=\frac{\operatorname{COD}_{H}}{\operatorname{COD} p\left(t_{0}\right)}
$$

Where $C O D_{p}\left(t_{0}\right)$ is the initial particulate $\mathrm{COD}$ in the reactor.

In the following paragraphs, all terms are expressed in $\mathrm{g}_{\mathrm{COD}} / \mathrm{kg}_{\mathrm{RM}}$ (grams of COD per $\mathrm{kg}$ unit mass of raw medium).

\subsection{Biochemical methane potential (BMP)}

Four series of BMP tests were undertaken for each run: $t_{0}, t_{24}, t_{48}$ and $t_{72}$. $t_{0}$ represents the reference sample "without hydrolytic stage" and it will be considered as the baseline (similar to what would happen in a single stage process). $t_{24}, t_{48}$ and $t_{72}$ refers respectively to 24,48 and $72 \mathrm{~h}$ of hydrolysis. $1000 \mathrm{~mL}$ bottles were used for raw samples, $500 \mathrm{~mL}$ bottles for the soluble fraction. The tests were performed according to the guidelines provided by the BMP international working group (Holliger et al., 2016). Substrate to Inoculum ratio was $\mathrm{S} / \mathrm{I}=0.5$, on a VS basis. The same nutrient media was used for all the tests and the same inoculum for each hydrolysis experiment. This point is crucial because the use of the same inoculum permits to compare the kinetic responses of the methane production as a function of the hydrolysis time. The anaerobic inoculum was a digested sludge provided by the nearby wastewater treatment plant (La Feyssine WWTP, Lyon, 
France). It was stored for 1 week in a temperature controlled room $\left(35 \pm 1^{\circ} \mathrm{C}\right)$ and kept in the same conditions for all the runs to ensure comparisons between each run.

For each run (i.e. each hydrolysis experiment), in parallel with $t_{0}$, two blank tests were performed: the "conventional blanks" for calculating the endogenous methane production from the anaerobic inoculum, and the "positive blanks" combining both the BMP inoculum and the "digested OFMSW" inoculum used for the experiment. This was done in order to assess the methane production of the inoculum used in the reactor (paragraph 2.1). The biogas production was determined with the manometric method. Headspace pressure was measured with a Digitron precision manometer. The biogas was vented when the pressure was higher than 1500 mbar. The biogas composition was measured by gas chromatography (section 2.3). The pressure after venting and/or biogas composition measurement was also recorded, which enabled to calculate the methane produced between two measurements. Biogas and methane production were calculated in STP conditions $\left(0^{\circ} \mathrm{C}, 101325 \mathrm{~Pa}\right)$ after correction for moisture. For the raw samples, the BMP were performed in triplicate, and in duplicate only for soluble samples. For each run (72 $\mathrm{h}$ of durations) 26 BMP bottles were run ( 6 subsamples for the blank tests, and 5 for each sampling time $t_{j}$ ).

For each test, the net methane production (without inoculum) was fitted to a first order model using the Excel $^{\mathrm{TM}}$ solver with the least square method. The resulting model equation was:

$$
V_{C H_{4}}(t)=B M P \cdot\left(1-e^{-k t}\right)
$$

where $V_{C H 4}(t)$ represent the methane produced at time $t\left(\mathrm{~mL}_{\mathrm{CH}} / \mathrm{g}_{\mathrm{VS}}\right), B M P$ the biochemical methane potential $\left(\mathrm{mL}_{\mathrm{CH} 4} / \mathrm{g}_{\mathrm{VS}}, \mathrm{STP}\right)$ and $k$ the $1^{\text {st }}$-order kinetic constant $\left(\mathrm{d}^{-}\right.$ $\left.{ }^{1}\right)$. In view of comparing the different tests, a variation index $(\lambda)$ has been defined for $k$ and $B M P$ values: $\lambda_{k}\left(t_{i}\right)=\frac{k_{t i}}{k_{t 0}}, \lambda_{B M P}\left(t_{i}\right)=\frac{B M P_{t i}}{B M P_{t 0}}$ where $t_{i}$ is the hydrolysis time and $t_{0}$ 
the initial sample. Each $\lambda$ value represents the normalized effect of the hydrolysis stage of the TPAD process compared to a single stage process operated at $37^{\circ} \mathrm{C}$.

\section{Results and Discussion}

Considering the experimental plan, different effects were analysed. A particular attention was paid to the different hydrolysis temperature (Exp. $1-2-3$ ) and OFMSW characteristics (Exp. 4 - 5). The DS effects (exp. 2-5) were not significant; therefore, they will not be discussed in the following sections. The detailed characterization of the initial composition of co-digestion mixtures are given in Supplementary Materials Table S1.

\subsection{Temperature effect}

The effect of temperature can be evaluated with experiments 1, 2 and 3 (Table 2). The substrate mixture was the same: OFMSW_2 - DS_2. The only difference was the inoculum, which was changed according to the temperature (mesophilic inoculum for experiment 1, thermophilic for experiment 2 and 3 ). Table 3 shows the most relevant results. 
Table 3. Results of analyses on soluble fraction ( $\mathrm{pH}, \mathrm{COD})$ and biogas production during the hydrolytic stage for the experiments 1,2 and 3 (* measure not available)

\begin{tabular}{|c|c|c|c|c|c|}
\hline & & $t_{0}$ & $t_{24}$ & $t_{48}$ & $t_{72}$ \\
\hline \multirow{7}{*}{$\begin{array}{c}\text { Exp. } 1 \\
37^{\circ} \mathrm{C}\end{array}$} & $\overline{\mathrm{pH}}$ & 7.50 & 7.70 & 7.50 & 7.00 \\
\hline & CODs (g/kgRM) & 24 & 25 & 26 & 27 \\
\hline & $\mathrm{COD}_{\mathrm{H}}(\mathrm{g} / \mathrm{kgRM})$ & - & 3 & 6 & 9 \\
\hline & $\mathrm{Y}_{\mathrm{H}}$ & - & $1.7 \%$ & $3.5 \%$ & $5.2 \%$ \\
\hline & $\mathrm{V}$ biogas $(\mathrm{L})$ & - & 26.8 & 39.9 & 58.32 \\
\hline & $\mathrm{H}_{2}(\%)$ & - & 0 & 0 & 0 \\
\hline & $\mathrm{CH}_{4}(\%)$ & - & 22.5 & 30.4 & 31.6 \\
\hline \multirow{7}{*}{$\begin{array}{c}\text { Exp. } 2 \\
55^{\circ} \mathrm{C}\end{array}$} & $\mathrm{pH}$ & 7.36 & 7.32 & 6.89 & 6.64 \\
\hline & CODs (g/kgRM) & 38 & 41 & 42 & $*$ \\
\hline & $\mathrm{COD}_{\mathrm{H}}(\mathrm{g} / \mathrm{kgRM})$ & - & 8 & 12 & $*$ \\
\hline & $\mathrm{Y}_{\mathrm{H}}$ & - & $3.8 \%$ & $5.7 \%$ & $*$ \\
\hline & $\mathrm{V}$ biogas $(\mathrm{L})$ & - & 60.5 & 70.4 & 74.0 \\
\hline & $\mathrm{H}_{2}(\%)$ & - & 0.6 & 0 & 0 \\
\hline & $\mathrm{CH}_{4}(\%)$ & - & 29.9 & 41.5 & 44 \\
\hline \multirow{7}{*}{$\begin{array}{c}\text { Exp. } 3 \\
65^{\circ} \mathrm{C}\end{array}$} & $\mathrm{pH}$ & 7.36 & 6.93 & 7.31 & 6.82 \\
\hline & CODs (g/kgRM) & 32 & 34 & 35 & 36 \\
\hline & $\mathrm{COD}_{\mathrm{H}}(\mathrm{g} / \mathrm{kgRM})$ & - & 3 & 5 & 11 \\
\hline & $\mathrm{Y}_{\mathrm{H}}$ & - & $1.5 \%$ & $2.5 \%$ & $5.4 \%$ \\
\hline & $\mathrm{V}$ biogas $(\mathrm{L})$ & - & 34.4 & 37.6 & 74.0 \\
\hline & $\mathrm{H}_{2}(\%)$ & - & 47.3 & 12.6 & 9.6 \\
\hline & $\mathrm{CH}_{4}(\%)$ & - & 1.0 & 15.3 & 30.1 \\
\hline
\end{tabular}

The $\mathrm{pH}$ decreased after $72 \mathrm{~h}$ for all experiments. The $\mathrm{pH}$ drop was more pronounced in Exp. 2, which was probably due to a different buffer capacity. Indeed, the changes in $\mathrm{pH}$ due to the organic acids formed might have got buffered by the bicarbonate alkalinity of the inoculum. The biogas composition was different between $37-55^{\circ} \mathrm{C}$ and $65^{\circ} \mathrm{C}$. At 37 and $55^{\circ} \mathrm{C}, \mathrm{H}_{2}$ production was very low. Meanwhile, an important production of $\mathrm{CH}_{4}$ was observed during the first $48 \mathrm{~h}$. On the other hand, we noticed an important $\mathrm{H}_{2}$ production after $24 \mathrm{~h}$ at $65^{\circ} \mathrm{C}$. We know that the production of $\mathrm{H}_{2}$ (and VFA) in the hydrolytic stage is a consequence of the acidogenic fermentation of easily biodegradable compounds (Batstone et al., 2014; Chu et al., 2008). It is reasonable to think that in the first 24 hours, hydrogen build-up occurred in all experiments. At 37 and $55^{\circ} \mathrm{C}$, hydrogenotrophic 
methanogenesis probably occurred more quickly than at $65^{\circ} \mathrm{C}$. Indeed, at $65^{\circ} \mathrm{C}$ the uptake of hydrogen took place slowly between 24 and $72 \mathrm{~h}$ (decrease of $\mathrm{H}_{2}$ from $47.3 \%$ to $9.6 \%$ ). The amount of hydrolysed $\mathrm{COD}\left(\mathrm{COD}_{\mathrm{H}}\right)$ increased with time and the average hydrolysis rates were $0.125,0.25$ and $0.15 \mathrm{~g}_{\mathrm{COD}} \mathrm{kg} \mathrm{RM}^{-1} \mathrm{~h}^{-1}$ at 37,55 and $65^{\circ} \mathrm{C}$ respectively. The hydrolytic yield $\mathrm{Y}_{\mathrm{H}}$ remained relatively moderated (below 6\%) and the most elevated value was obtained at $55^{\circ} \mathrm{C}$.

The better hydrolysis performances were obtained at $55^{\circ} \mathrm{C}$. The effect of temperature on hydrolysis has been studied by several authors between 20 and $70^{\circ} \mathrm{C}$ (Arras et al., 2019; Cheah et al., 2018; Krause et al., 2018; Nilsson Påledal et al., 2018; Soomro et al., 2020). The temperature of $55^{\circ} \mathrm{C}$ was often found optimal for hydrolysis (Lee et al., 2008; Nges and Liu, 2009)on waste activated sludge or kitchen waste. However, a higher hydrolysis efficiency was not always found correlated with high performances of the second-stage methanogenic reactor, as observed by Ge et al., (2011a) on waste activated sludge, and Buffière et al., (2018) on cattle slurry mixed with maize silage.

The profiles of VFAs shows the evolution of the most important acids during the $72 \mathrm{~h}$ of hydrolytic stage (Figure 1). 


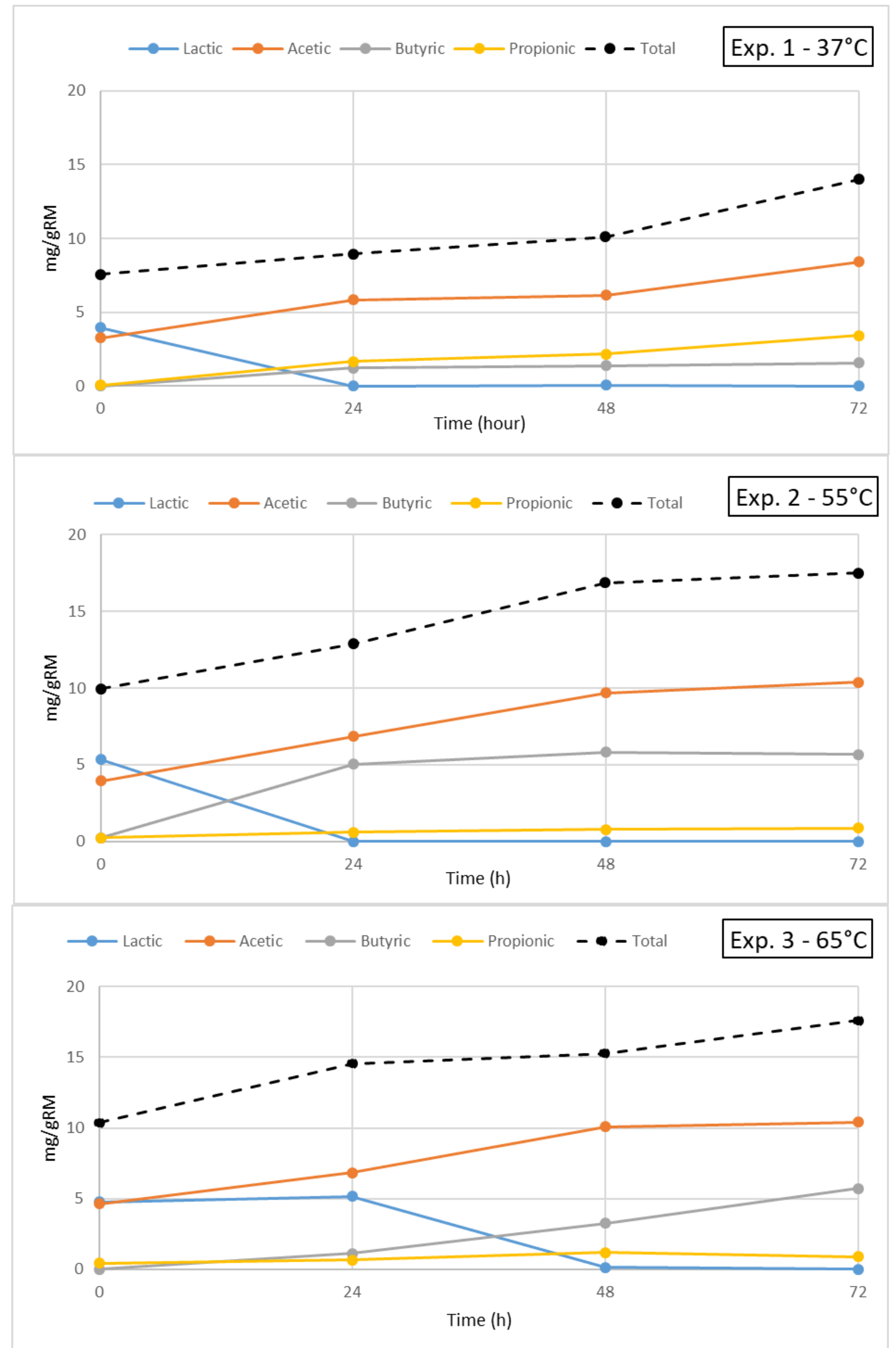

Figure 1 - VFAs evolution during the hydrolytic stage for experiments 1, 2 and 3 (respectively at 37,55 and $65^{\circ} \mathrm{C}$ ). Values expressed in $\mathrm{mg}^{-1} \mathrm{~g}^{-1}$ of Raw Material (RM). 
Initial concentration of total VFA were almost similar for all experiments $\left(7.56 \mathrm{mg} / \mathrm{g}_{\mathrm{RM}}\right.$ for exp.1, $9.96 \mathrm{mg} / \mathrm{g}_{\mathrm{RM}}$ for exp.2 and $10.36 \mathrm{mg} / \mathrm{g}_{\mathrm{RM}}$ for exp.3). In all cases the total concentration of VFAs increased during the experiments by about $7 \mathrm{mg} / \mathrm{gRM}$, which indicates that the hydrolytic activity was followed by acidogenesis (Magdalena et al., 2019). Initial VFAs were mostly distributed between lactic and acetic acid (around 5 $\mathrm{mg} / \mathrm{g}_{\mathrm{RM}}$ for Exp. 2 and 3 and around $3.5 \mathrm{mg} / \mathrm{g}_{\mathrm{RM}}$ for Exp.1). The time course of each acid showed the rapid consumption of lactic acid (after $24 \mathrm{~h}$ for experiment 1 and 2, after 48 $\mathrm{h}$ for experiment 3) and a consequent production of butyric acid, which is a common fermentative process (Teixeira Franco et al., 2016). Butyric acid is weaker than lactic acid, and two moles of lactic acid are consumed for one mole of butyric acid produced. Consequently, this mechanism should lead to an increase of $\mathrm{pH}$ (McDonald et al. (1991) - The Biochemistry of Silage (page126-166)). This effect was however not observed in our case, since it was probably counterbalanced by additional acid producing mechanisms, as can be seen from the global increase of acetic acid concentrations (Batstone et al., 2014). All these features indicate a clear acidogenic activity.

Considering all the parameters analysed, it is possible to confirm that the temperature plays an important role on the hydrolytic stage. Specifically, observing the COD hydrolysis yield and the COD hydrolysis rate, $55^{\circ} \mathrm{C}$ was the optimal temperature.

\subsection{Effect of the type of OFMSW}

The comparison of experiments 4 and 5 can give an idea about the impact of the OFMSW characteristics on the hydrolytic stage (Table 4). 
Table 4. Results of analyses on soluble fraction ( $\mathrm{pH}, \mathrm{COD})$ and biogas production during the hydrolytic stage for the experiments 4 and 5 (* measure not available).

\begin{tabular}{cccccc}
\hline & & $t_{0}$ & $t_{24}$ & $t_{48}$ & $t_{72}$ \\
\hline & $\mathrm{pH}$ & 7.05 & 7.10 & 6.92 & 6.90 \\
& CODs (g/kgRM) & 58 & 57 & 60 & $*$ \\
Exp, 4 & $\mathrm{COD}_{\mathrm{H}}(\mathrm{g} / \mathrm{kgRM})$ & - & $*$ & $*$ & $*$ \\
OFMSW_1 & $\mathrm{Y}_{\mathrm{H}}$ & - & $*$ & $*$ & $*$ \\
\cline { 2 - 6 } & $\mathrm{V}$ biogas $(\mathrm{L})$ & $*$ & $*$ & $*$ & $*$ \\
& $\mathrm{H}_{2}(\%)$ & - & 9.2 & 6.7 & 4.4 \\
& $\mathrm{CH}_{4}(\%)$ & - & 20.1 & 30.5 & 31.9 \\
\hline \multirow{3}{*}{ Exp, 5 } & $\mathrm{pH}$ & 7.58 & 7.98 & 7.30 & 6.52 \\
OFMSW_2 & $\mathrm{CODS}(\mathrm{g} / \mathrm{kgRM})$ & 29 & 39 & 38 & 45 \\
\cline { 2 - 6 } & $\mathrm{CD}_{\mathrm{H}}(\mathrm{g} / \mathrm{kgRM})$ & - & 15 & 17 & 25 \\
& $\mathrm{Y}_{\mathrm{H}}$ & - & $7.3 \%$ & $8.3 \%$ & $12.2 \%$ \\
\hline & $\mathrm{H}_{2}(\%)$ & - & 50.4 & 65.0 & 67.6 \\
& $\mathrm{CH}_{4}(\%)$ & - & 5.1 & 8.2 & 5.3 \\
& & - & 35.4 & 40.8 & 43.0 \\
\hline
\end{tabular}

During experiment 5, a significant amount of biogas production was observed during the first 24 h of hydrolysis, similarly to Exp. 2. A concomitant increase of CODs was also noticed $(+34 \%)$ that resulted in a higher degree of hydrolysis $\mathrm{Y}_{\mathrm{H}}(12.2 \%$ is the highest value for all the experiments). The hydrolysis rate $\left(\mathrm{r}_{\mathrm{H}}\right)$ for exp. 5 was $0.32 \mathrm{~g}_{\mathrm{COD}} \mathrm{kg}_{\mathrm{RM}}{ }^{-1} \mathrm{~h}^{-}$ ${ }^{1}$ (highest value for all the experiments). Due to a technical problem, it was unfortunately not possible to calculate the hydrolysed $\mathrm{COD}\left(\mathrm{COD}_{\mathrm{H}}\right)$ for experiment 4.

The initial VFA profiles (Figure 2) were very different between exp. 4 and exp. 5. For experiment 4 the initial value was around $20 \mathrm{mg} / \mathrm{g}_{\mathrm{RM}}$, more than 2 times higher than exp. 5 (around $8 \mathrm{mg} / \mathrm{g}_{\mathrm{RM}}$ ). Furthermore, from the time course of VFAs concentration, we see that the total concentration remained constant in exp. 4 (around $20 \mathrm{mg} / \mathrm{g}_{\mathrm{RM}}$ ), while in exp. 5 it increased from 8 to $21 \mathrm{mg} / \mathrm{g}_{\mathrm{RM}}$.

For both experiments, the initial VFA composition was distributed between lactic and acetic acid (although at different concentrations). Concerning lactic acid, the same trend as experiments 1, 2 and 3 was observed in both cases: a rapid consumption after $24 \mathrm{~h}$ and 
a concomitant production of butyric acid. The main difference between exp. 4 and 5 was on acetic acid evolution: its concentration was constant during exp. 4, but raised after 72 h of hydrolysis during exp. 5. This trend was confirmed by the results presented on Table 4 for the COD (for exp. 4 only CODs). These observations show that during exp. 5, an important hydrolytic activity took place, while it was more limited during exp. 4. It is possible to explain this difference by the initial VFA concentration. The high initial concentration of VFA in exp. 4 value (acetic and lactic acid) indicates a difference in the initial characteristics between OFMSW_1 and OFMSW_2. Indeed, OFMSW_1 underwent a $48 \mathrm{~h}$ shipping time between on-site sampling and reception (and much probably different storage conditions), while OFMSW_2 was delivered in less than $24 \mathrm{~h}$. This explains why the hydrolytic performances obtained with OFMSW_1 are lower: it was indeed partly hydrolysed and acidified when the experiment started. 


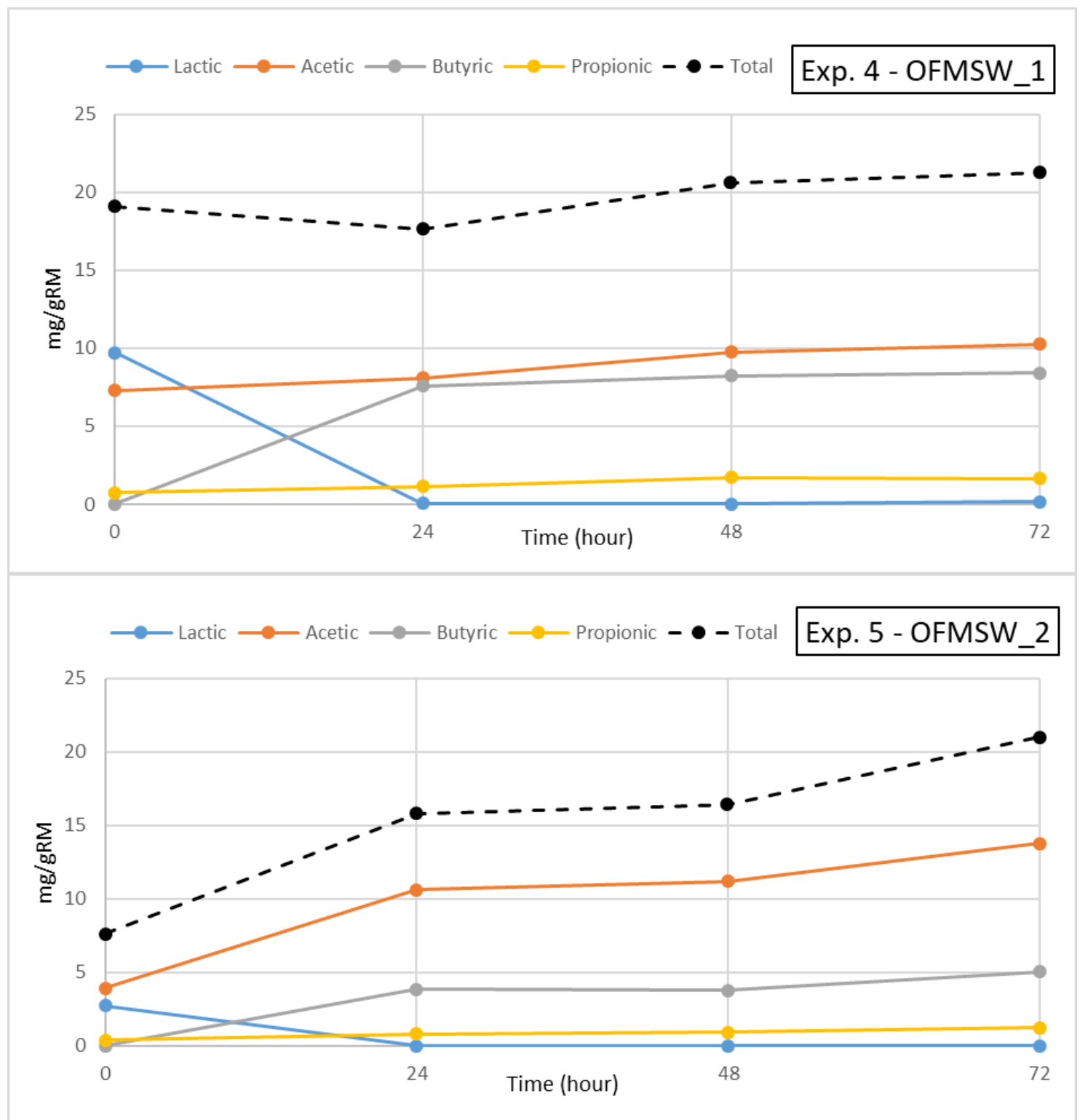

Figure 2 - VFAs evolution during hydrolytic stage for experiments 4 and 5 . Values expressed in $\mathrm{mg}^{-1} \mathrm{~g}^{-1}$ of raw material.

\subsection{Biochemical methane potential (BMP) results}

For each experiment, the absolute value of the BMP at $t_{0}$ was calculated as the reference basis to evaluate the effect of the hydrolytic stage (Table 5). The $\lambda_{\text {BMP }}\left(t_{i}\right)$ values represents the potential gain after hydrolytic stage as explained in section 2.4 (ratio between the BMP at $t_{i}$ and the BMP at $t_{0}$ ). The values in brackets were corrected by the methane produced during the hydrolysis itself (not available for experiment 4). Indeed, a significant amount of biogas was produced during hydrolysis (see Table 3 and Table 4) and this has to be accounted for in the estimation of the total methane production. 
Table 5. Effect of the hydrolysis on BMP. In brackets the values including the methane production during the hydrolytic stage (not available for experiment 4).

\begin{tabular}{|c|c|c|c|c|c|c|}
\hline \multicolumn{2}{|r|}{ Experiment } & \multirow{2}{*}{$\begin{array}{l}\text { Temp. } \\
37^{\circ} \mathrm{C}\end{array}$} & \multirow{2}{*}{$\begin{array}{c}\begin{array}{c}B M P t_{0} \\
\left(\mathrm{~mL}_{\mathrm{CH}} 4 \mathrm{gVs}^{-1}\right)\end{array} \\
206 \pm 5\end{array}$} & \multirow{2}{*}{$\begin{array}{c}\lambda_{B M P 24} \\
1.03 \pm 0.06 \\
(1.05)\end{array}$} & \multirow{2}{*}{$\begin{array}{c}\lambda_{B M P 48} \\
1.05 \pm 0.07 \\
(1.10)\end{array}$} & \multirow{2}{*}{$\begin{array}{c}\lambda_{B M P 72} \\
1.06 \pm 0.05 \\
(1.09)\end{array}$} \\
\hline 1 & $\begin{array}{c}O F M S W \_2+ \\
D S \_2\end{array}$ & & & & & \\
\hline 2 & $\begin{array}{c}\text { OFMSW_2 } \\
D S \_2\end{array}$ & $55^{\circ} \mathrm{C}$ & $237 \pm 5$ & $\begin{array}{c}1.04 \pm 0.05 \\
\quad(1.10)\end{array}$ & $\begin{array}{c}1.00 \pm 0.05 \\
\quad(1.09)\end{array}$ & $\begin{array}{l}0.94 \pm 0.03 \\
\quad(1.03)\end{array}$ \\
\hline 3 & $\begin{array}{c}O F M S W \_2+ \\
D S \_2\end{array}$ & $65^{\circ} \mathrm{C}$ & $242 \pm 6$ & $\begin{array}{c}1.00 \pm 0.04 \\
\quad(1.02)\end{array}$ & $\begin{array}{c}1.00 \pm 0.06 \\
\quad(1.02)\end{array}$ & $\begin{array}{c}1.03 \pm 0.08 \\
(1.10)\end{array}$ \\
\hline 4 & $\begin{array}{c}\text { OFMSW_1 } \\
D S_{-} 1\end{array}$ & $55^{\circ} \mathrm{C}$ & $214 \pm 3$ & $1.10 \pm 0.03$ & $1.14 \pm 0.02$ & $0.99 \pm 0.02$ \\
\hline 5 & $\begin{array}{c}\text { OFMSW_2 } \\
D S \_l\end{array}$ & $55^{\circ} \mathrm{C}$ & $210 \pm 11$ & $\begin{array}{c}1.16 \pm 0.09 \\
\quad(1.22)\end{array}$ & $\begin{array}{c}1.06 \pm 0.07 \\
\quad(1.16)\end{array}$ & $\begin{array}{c}1.10 \pm 0.06 \\
(1.19)\end{array}$ \\
\hline
\end{tabular}

Globally, the results show that the BMP increased $\left(\lambda_{\mathrm{BMP}} t_{i}>1\right)$ but, considering the standard deviations, the difference was generally not significant. The highest effect was observed for exp. 5, with $22 \%$ improvement after $24 \mathrm{~h}$ hydrolysis.

The analyses of the first three experiments did not show any particular effect of temperature. In exp. 4 and 5 however, we observed an effect of the type of OFMSW: OFMSW_2 turned out to be more positively impacted by the hydrolytic stage in terms of BMP values.

To deepen the understanding of the role of the hydrolytic stage during AD, BMP tests on the soluble fraction were carried out (Paragraph 2.4). The objective was to evaluate the contribution of the soluble fraction on the total methane production (Supplementary Materials Table S2). For all experiments, the contribution of the soluble fraction increased. After $24 \mathrm{~h}$, an improvement of around 6-9\% was observed in all conditions. On the opposite, between 48 and $72 \mathrm{~h}$, all values tend to stabilize.

\subsection{Methane production kinetics}

As described in Paragraph 2.4, the net methane production curves obtained during the BMP tests were fitted to a first order model. Indeed, the variation of the kinetic constant 
$k\left(\mathrm{~d}^{-1}\right)$ for BMP tests performed with the same inoculum at the same time was considered as a valuable indicator of the effect of the pre-treatment on the methane production rate. The results are reported in Table 6: $k$-values at $t_{0}$, and relative increase coefficients after 24,48 and $72 \mathrm{~h}$ of hydrolysis ( $\lambda_{\mathrm{k}}\left(t_{i}\right)$ values).

Table 6. Hydrolysis effect on the methane production rate ( $1^{\text {st }}$ order kinetic constant $\left.k\right)$.

\begin{tabular}{|c|c|c|c|c|c|c|}
\hline & Experiment & Temp. & $k t_{0}\left(\mathrm{~d}^{-1}\right)$ & $\lambda_{\mathrm{k} 24}$ & $\lambda_{\mathrm{k} 48}$ & $\lambda_{\mathrm{k} 72}$ \\
\hline 1 & $\begin{array}{c}O F M S W \_2+ \\
D S \_2\end{array}$ & $37^{\circ} \mathrm{C}$ & $0.15 \pm 0.003$ & $1.16 \pm 0.10$ & $1.24 \pm 0.05$ & $1.10 \pm 0.06$ \\
\hline 2 & $\begin{array}{c}O F M S W \_2 \\
D S \_2\end{array}$ & $55^{\circ} \mathrm{C}$ & $0.20 \pm 0.002$ & $1.02 \pm 0.07$ & $1.11 \pm 0.07$ & $1.19 \pm 0.03$ \\
\hline 3 & $\begin{array}{c}O F M S W \_2 \\
D S \_2\end{array}$ & $65^{\circ} \mathrm{C}$ & $0.22 \pm 0.003$ & $1.18 \pm 0.04$ & $1.30 \pm 0.05$ & $1.24 \pm 0.11$ \\
\hline 4 & $\begin{array}{c}\text { OFMSW_l } W_{-}+ \\
D S_{-} l\end{array}$ & $55^{\circ} \mathrm{C}$ & $0.25 \pm 0.00$ & $1.10 \pm 0.02$ & $0.91 \pm 0.03$ & $1.00 \pm 0.06$ \\
\hline 5 & $\begin{array}{c}\text { OFMSW_2 } \\
D S \_\end{array}$ & $55^{\circ} \mathrm{C}$ & $0.23 \pm 0.01$ & $1.11 \pm 0.07$ & $1.27 \pm 0.11$ & $1.47 \pm 0.09$ \\
\hline
\end{tabular}

The methane production kinetics showed a global improvement upon hydrolysis, with an increase of the kinetic constant comprised between $2 \%$ and $18 \%$ after $24 \mathrm{~h}$ and between 0 and $47 \%$ after $72 \mathrm{~h}$. The best results $(+47 \%)$ were obtained with OFMSW 2 after $72 \mathrm{~h}$ of hydrolysis at $55^{\circ} \mathrm{C}$ (experiment 5). This result was obtained with all the tested temperature. However, we confirmed the importance of OFMSW type: exp. 5 (made with OFMSW_2) showed higher values of $\lambda_{k}$ compared to exp. 4 (made with OFMSW_1).

\section{Discussion}

The results of this study gave some additional information about the role of hydrolytic stage on co-digestion of OFMSW and DS in TPAD.

The hydrolytic stage improved slightly the amount of methane produced. A similar limited effect of TPAD on OFMSW was found by Lavagnolo et al., (2018), by Buffière et al., (2018) on a mixture of cattle slurry and maize silage, by Xiao et al. (2018) and by 
Wu et al. (2015) on Food Waste. The highest improvement $\left(+22 \%, \mathrm{~T}=55^{\circ} \mathrm{C}-\mathrm{SRT}=24\right.$ h) was observed for exp. 5. Orozco et al. (2013) found an increase of the BMP (30\%) after $96 \mathrm{~h}$ of hydrolysis at $55^{\circ} \mathrm{C}$ for grass silage. The contribution of the soluble fraction on the total methane production (Supplementary Materials Table S2) confirmed that $24 \mathrm{~h}$ of hydrolysis was the most effective SRT. Other studies obtained similar trends: Buffière et al. (2018) on a mixture of cattle slurry and maize silage, and Ge et al. (2011a, 2011b) for waste activated sludge.

The most striking effect was the improvement of methane production kinetics after the hydrolytic stage. First of all, the $1^{\text {st }}$ order kinetic constant $k$ (around $0.2 \mathrm{~d}^{-1}$ ) can be considered as elevated in the anaerobic digestion context (Batstone et al., 2009). Experiment 5 gave the best improvement for $k(+47 \%)$ at $55^{\circ} \mathrm{C}$ and $72 \mathrm{~h}$ of SRT. These results confirm the general trends observed by many authors (Buffière et al., 2018; Fernández-Rodríguez et al., 2015; Romero Aguilar et al., 2013). It is very important to point out that the highest improvement of the kinetics was obtained for experiment 5, and the lowest value for experiment 4. Considering our dataset, we noted that the substrate mix used in experiment 5 had the lowest VFA content at $t_{0}$, contrary to that of exp. 4 (high VFAs concentration values at $t_{0}$ ). Indeed, we observed no noticeable increase of acetic acid concentration in exp. 4, while in exp. 5 it becomes more than double after $72 \mathrm{~h}$. This trend is also confirmed by the COD concentrations and by the hydrolysis yield $\left(\mathrm{Y}_{\mathrm{H}}\right)$ (Table 3 and Table 4). Considering that the only difference between exp. 4 and exp. 5 is the type of the OFMSW, it is possible to conclude that, for exp. 4, the hydrolysisacidogenesis steps were already initiated in the substrate - even before the start of the experiment - probably during all the above steps: preparation, transport, storage etc.

Furthermore, this hypothesis is confirmed by the different shipping time between OFMSW_1 and OFMSW_2 as describe in paragraph 2.2. This points the importance of 
sampling and storage conditions for fresh waste characterization, especially when the sampling is performed in remote industrial sites (Teixeira Franco et al., 2017).

In terms of reactor configuration and design, the consequences of the use of a 2-stage system compared to single-stage mesophilic reactor are interesting. From our results, we have estimated the percentage of the initial BMP that can be achieved under different reactor configurations for different retention times. We have compared a single-stage mesophilic reactor with two-stage systems with different temperature in the first-stage, according to our results for different SRT, from 20 to 40 days (Table 7). We have used a $1^{\text {st }}$ order model to calculate the methane produced from the methanogenic (mesophilic).

Table 7. Estimation of the percentage of the initial BMP obtained from 2-stage vs onestage TPAD systems.

\begin{tabular}{ccccc}
\hline & One stage & \multicolumn{3}{c}{ Two-stage } \\
\cline { 3 - 5 } Total SRT (days) & $\mathbf{3 7} \mathbf{C}$ & $37^{\circ}-37^{\circ} \mathrm{C}$ & $55^{\circ}-37^{\circ} \mathrm{C}$ & $65^{\circ}-37^{\circ} \mathrm{C}$ \\
\hline $\mathbf{2 0}$ & $80 \%$ & $89 \%$ & $99 \%$ & $90 \%$ \\
\hline $\mathbf{2 5}$ & $83 \%$ & $93 \%$ & $103 \%$ & $94 \%$ \\
\hline $\mathbf{3 0}$ & $86 \%$ & $96 \%$ & $106 \%$ & $96 \%$ \\
\hline $\mathbf{4 0}$ & $89 \%$ & $99 \%$ & $109 \%$ & $100 \%$ \\
\hline
\end{tabular}

For the two-stage systems, the SRT in the first stage was taken constant (3 days): it means that the methane production in the second stage was calculated with a SRT of 17, 22, 27 and 37 days. For the calculations, we accounted for the increase of the BMP and the increase of the kinetic constant obtained experimentally (from Table 5 and 6, respectively). The improvement is noticeable for all two-stage systems, the most efficient being the one with the thermophilic $1^{\text {st }}$ stage. 


\section{Conclusions}

This experimental investigation demonstrated that a two-stage operation was a valuable solution for the anaerobic digestion of the organic fraction of municipal solid waste. We found that the first hydrolytic stage slightly improved the methane yield (between 0 to $15 \%$, depending on temperature and incoming feedstock). However, the most striking effect was obtained for the methane production kinetics, which noticeably increased (up to $40 \%$ ) in the second stage.

From a mechanistic point of view, this means that a pre-fermentation step generates changes in the structure of the organic matter that make it more available and more accessible to further degradation.

From an operational point of view, this means that under optimal conditions $\left(55^{\circ} \mathrm{C}\right.$ and 3 days retention time in the first stage and $37^{\circ} \mathrm{C}$ in the second stage), a temperature-phased anaerobic digestion system would be able to produce 10 to $20 \%$ more methane than a single stage mesophilic reactor operated under the same total retention time.

\section{Acknowledgments}

We want to thank the technical team involved in the project: Nathalie Dumont, Richard Poncet, Hervé Perier-Camby. A special acknowledgment to SIAAP and SYCTOM who funded the work and Arkolia Energies. This work was realised within the Graduate School $\mathrm{H}_{2} \mathrm{O}$ 'Lyon (ANR-17-EURE-0018) and Université de Lyon (UdL), as part of the programme "Investissements d'Avenir " run by Agence Nationale de la Recherche (ANR). 


\section{References}

Appels, L., Baeyens, J., Degrève, J., Dewil, R., 2008. Principles and potential of the anaerobic digestion of waste-activated sludge. Prog. Energy Combust. Sci. 34, 755781. https://doi.org/10.1016/j.pecs.2008.06.002

Arras, W., Hussain, A., Hausler, R., Guiot, S.R., 2019. Mesophilic, thermophilic and hyperthermophilic acidogenic fermentation of food waste in batch: Effect of $\begin{array}{llll}\text { inoculum } & \text { source. } & \text { Waste }\end{array}$ https://doi.org/10.1016/j.wasman.2019.02.011

Batstone, D.J., Keller, J., Angelidaki, I., Kalyuzhnyi, S.V., Pavlostathis, S.G., Rozzi, A., Sanders, W.T.M., H. Siegrist, Vavilin, V.A., 2014. Anaerobic Digestion Model N 1 1. https://doi.org/10.2166/9781780403052

Batstone, D.J., Tait, S., Starrenburg, D., 2009. Estimation of hydrolysis parameters in full-scale anerobic digesters. Biotechnol. Bioeng. 102, 1513-1520. https://doi.org/10.1002/bit.22163

Borowski, S., 2015. Temperature-phased anaerobic digestion of the hydromechanically separated organic fraction of municipal solid waste with sewage sludge. Int. Biodeterior. Biodegrad. 105, 106-113. https://doi.org/10.1016/j.ibiod.2015.08.022

Bouallagui, H., Lahdheb, H., Romdan, E. Ben, Rachdi, B., Hamdi, M., 2009. Improvement of fruit and vegetable waste anaerobic digestion performance and stability with co-substrates addition. J. Environ. Manage. 90, 1844-1849. https://doi.org/10.1016/j.jenvman.2008.12.002

Bougrier, C., Delgenès, J.P., Carrère, H., 2008. Effects of thermal treatments on five different waste activated sludge samples solubilisation, physical properties and anaerobic digestion. Chem. Eng. J. 139, 236-244. https://doi.org/10.1016/j.cej.2007.07.099

Buffière, P., Dooms, M., Hattou, S., Benbelkacem, H., 2018. The hydrolytic stage in high 
solids temperature phased anaerobic digestion improves the downstream methane production rate. Bioresour. Technol. 259, 111-118. https://doi.org/10.1016/j.biortech.2018.03.037

Chatterjee, B., Mazumder, D., 2019. Role of stage-separation in the ubiquitous development of Anaerobic Digestion of Organic Fraction of Municipal Solid Waste : A critical review. Renew. Sustain. Energy Rev. 104, 439-469. https://doi.org/10.1016/j.rser.2019.01.026

Chatterjee, B., Mazumder, D., 2016. Anaerobic Digestion for the Stabilization of the Organic Fraction of Municipal Solid Waste: A Review. Environ. Rev. 24, 426-459.

Cheah, Y.K., Vidal-Antich, C., Dosta, J., Mata-Álvarez, J., 2018. Study of the effects of temperature and $\mathrm{pH}$ on acidogenic fermentation process from organic fraction of municipal solid waste, in: 6th International Conference on Sustainable Solid Waste Management.

Chu, C.F., Li, Y.Y., Xu, K.Q., Ebie, Y., Inamori, Y., Kong, H.N., 2008. A pH- and temperature-phased two-stage process for hydrogen and methane production from food waste. Int. J. Hydrogen Energy 33, 4739-4746. https://doi.org/10.1016/j.ijhydene.2008.06.060

Feng, K., Wang, Q., Li, H., Zhang, Y., Deng, Z., Liu, J., Du, X., 2020. Effect of fermentation type regulation using alkaline addition on two-phase anaerobic digestion of food waste at different organic load rates. Renew. Energy 154, 385393. https://doi.org/10.1016/j.renene.2020.03.051

Fernández-Rodríguez, J., Pérez, M., Romero, L.I., 2016. Semicontinuous TemperaturePhased Anaerobic Digestion (TPAD) of Organic Fraction of Municipal Solid Waste (OFMSW). Comparison with single-stage processes. Chem. Eng. J. 285, 409-416. https://doi.org/10.1016/j.cej.2015.10.027

Fernández-Rodríguez, J., Pérez, M., Romero, L.I., 2015. Temperature-phased anaerobic 
digestion of Industrial Organic Fraction of Municipal Solid Waste: A batch study. Chem. Eng. J. 270, 597-604. https://doi.org/10.1016/j.cej.2015.02.060

Franco, R.T., Bayard, R., Buffière, P., 2019. An improved methodology to assess the organic biodegradability and the biomethane potential of organic wastes for anaerobic digestion. https://doi.org/10.1177/0734242X19851201

Ge, H., Jensen, P.D., Batstone, D.J., 2011a. Temperature phased anaerobic digestion increases apparent hydrolysis rate for waste activated sludge. Water Res. 45, 15971606. https://doi.org/10.1016/j.watres.2010.11.042

Ge, H., Jensen, P.D., Batstone, D.J., 2011b. Increased temperature in the thermophilic stage in temperature phased anaerobic digestion (TPAD) improves degradability of waste activated sludge. J. Hazard. Mater. 187, 355-361. https://doi.org/10.1016/j.jhazmat.2011.01.032

Ge, H., Jensen, P.D., Batstone, D.J., 2010. Pre-treatment mechanisms during thermophilic-mesophilic temperature phased anaerobic digestion of primary sludge. Water Res. 44, 123-130. https://doi.org/10.1016/j.watres.2009.09.005

Han, Y., Sung, S., Dague, R.R., 1997. Temperature-phased anaerobic digestion of wastewater sludges. Water Sci. Technol. 36, 367-374. https://doi.org/10.1016/S0273-1223(97)00544-1

Harris, W.L., Dague, R.R., 1993. Comparative performance of anaerobic filters at mesophilic and thermophilic temperatures. Water Environ. Res. 65, 764-771. https://doi.org/10.2175/wer.65.6.9

Holliger, C., Alves, M., Andrade, D., Angelidaki, I., Astals, S., Baier, U., Bougrier, C., Buffière, P., Carballa, M., De Wilde, V., Ebertseder, F., Fernández, B., Ficara, E., Fotidis, I., Frigon, J.C., De Laclos, H.F., Ghasimi, D.S.M., Hack, G., Hartel, M., Heerenklage, J., Horvath, I.S., Jenicek, P., Koch, K., Krautwald, J., Lizasoain, J., Liu, J., Mosberger, L., Nistor, M., Oechsner, H., Oliveira, J.V., Paterson, M., Pauss, 
A., Pommier, S., Porqueddu, I., Raposo, F., Ribeiro, T., Pfund, F.R., Strömberg, S., Torrijos, M., Van Eekert, M., Van Lier, J., Wedwitschka, H., Wierinck, I., 2016. Towards a standardization of biomethane potential tests. Water Sci. Technol. 74, 2515-2522. https://doi.org/10.2166/wst.2016.336

ISO 14235. Soil quality - Determination of organic carbon by sulfochromic oxidation, 1998.

Kaiser, S.K., Dague, R.R., 1994. The temperature-phased anaerobic biofilter process. Water Sci. Technol. 29, 213-223. https://doi.org/10.2166/wst.1994.0483

Kim, H.-W., Nam, J.-Y., Shin, H.-S., 2011. A comparison study on the high-rate codigestion of sewage sludge and food waste using a temperature-phased anaerobic sequencing batch reactor system. Bioresour. Technol. 102, 7272-9. https://doi.org/10.1016/j.biortech.2011.04.088

Krause, M.J., Chickering, G.W., Townsend, T.G., Pullammanappallil, P., 2018. Effects of temperature and particle size on the biochemical methane potential of municipal solid waste components. Waste Manag. 71, 25-30. https://doi.org/10.1016/j.wasman.2017.11.015

Kreuger, E., Nges, I., Björnsson, L., 2011. Ensiling of crops for biogas production: Effects on methane yield and total solids determination. Biotechnol. Biofuels 4, 44. https://doi.org/10.1186/1754-6834-4-44

Lavagnolo, M.C., Girotto, F., Rafieenia, R., Danieli, L., Alibardi, L., 2018. Two-stage anaerobic digestion of the organic fraction of municipal solid waste - Effects of process conditions during batch tests. Renew. Energy 126, 14-20. https://doi.org/10.1016/j.renene.2018.03.039

Lee, M., Hidaka, T., Tsuno, H., 2008. Effect of temperature on performance and microbial diversity in hyperthermophilic digester system fed with kitchen garbage. Bioresour. Technol. 99, 6852-6860. https://doi.org/10.1016/j.biortech.2008.01.038 
Li, L., Kong, Z., Qin, Y., Wu, J., Zhu, A., Xiao, B., Ni, J., Kubota, K., Li, Y., 2020. Temperature-phased anaerobic co-digestion of food waste and paper waste with and without recirculation: Biogas production and microbial structure. Sci. Total Environ. 724, 1-9. https://doi.org/10.1016/j.scitotenv.2020.138168

Li, Y., Chen, Y., Wu, J., 2019. Enhancement of methane production in anaerobic digestion process: A review. Appl. Energy 240, 120-137. https://doi.org/10.1016/j.apenergy.2019.01.243

Lv, W., Zhang, W., Yu, Z., 2016. Volume ratios between the thermophilic and the mesophilic digesters of a temperature-phased anaerobic digestion system affect their performance and microbial communities. N. Biotechnol. 33, 245-254. https://doi.org/10.1016/j.nbt.2015.07.001

Magdalena, J.A., Llamas, M., Tomás-Pejó, E., González-Fernández, C., 2019. Semicontinuous anaerobic digestion of protease pretreated Chlorella biomass for volatile fatty acids production. J. Chem. Technol. Biotechnol. 94, 1861-1869. https://doi.org/10.1002/jctb.5960

McDonald et al. (1991) - The Biochemistry of Silage (page126-166).pdf, n.d.

Montañés Alonso, R., Solera del Río, R., Pérez García, M., 2016. Thermophilic and mesophilic temperature phase anaerobic co-digestion (TPAcD) compared with single-stage co-digestion of sewage sludge and sugar beet pulp lixiviation. Biomass and Bioenergy 93, 107-115. https://doi.org/10.1016/j.biombioe.2016.05.028

Nges, I.A., Liu, J., 2009. Effects of anaerobic pre-treatment on the degradation of dewatered-sewage sludge. Renew. Energy 34, 1795-1800. https://doi.org/10.1016/j.renene.2008.12.001

Nilsson Påledal, S., Hellman, E., Moestedt, J., 2018. The effect of temperature, storage time and collection method on biomethane potential of source separated household food waste. Waste Manag. 71, 636-643. 
https://doi.org/10.1016/j.wasman.2017.05.034

Oles, J., Dichtl, N., Niehoff, H.H., 1997. Full scale experience of two stage thermophilic/mesophilic sludge digestion. Water Sci. Technol. 36, 449-456. https://doi.org/10.1016/S0273-1223(97)00554-4

Orozco, A.M., Nizami, A.S., Murphy, J.D., Groom, E., 2013. Optimizing the thermophilic hydrolysis of grass silage in a two-phase anaerobic digestion system. Bioresour. Technol. 143, 117-125. https://doi.org/10.1016/j.biortech.2013.05.118

Paudel, S., Kang, Y., Yoo, Y.S., Seo, G.T., 2017. Effect of volumetric organic loading rate (OLR) on $\mathrm{H} 2$ and $\mathrm{CH} 4$ production by two-stage anaerobic co-digestion of food waste and brown water. Waste Manag. 61, 484-493. https://doi.org/10.1016/j.wasman.2016.12.013

Porter, M.G., Murray, R.S., 2001. The volatility of components of grass silage on oven drying and the inter-relationship between dry-matter content estimated by different analytical methods. Grass Forage Sci. 56, 405-411. https://doi.org/10.1046/j.13652494.2001.00292.x

Prabhu, A.V., Raja, S.A., Avinash, A., Pugazhendhi, A., 2020. Parametric optimization of biogas potential in anaerobic co-digestion of biomass wastes. Fuel 119574. https://doi.org/10.1016/j.fuel.2020.119574

Qin, Y., Li, L., Wu, J., Xiao, B., Hojo, T., Kubota, K., Cheng, J., 2019. Bioresource Technology Co-production of biohydrogen and biomethane from food waste and paper waste via recirculated two-phase anaerobic digestion process : Bioenergy yields and metabolic distribution 276, 325-334. https://doi.org/10.1016/j.biortech.2019.01.004

Qin, Y., Wu, J., Xiao, B., Hojo, T., Li, Y.Y., 2018. Biogas recovery from two-phase anaerobic digestion of food waste and paper waste: Optimization of paper waste addition. Sci. Total Environ. 634, 1222-1230. 
https://doi.org/10.1016/j.scitotenv.2018.03.341

Romero-Güiza, M.S., Peces, M., Astals, S., Benavent, J., Valls, J., Mata-Alvarez, J., 2014. Implementation of a prototypal optical sorter as core of the new pre-treatment configuration of a mechanical-biological treatment plant treating OFMSW through anaerobic digestion. Appl. Energy 135, 63-70. https://doi.org/10.1016/j.apenergy.2014.08.077

Romero Aguilar, M.A., Fdez-Güelfo, L.A., álvarez-Gallego, C.J., Romero García, L.I., 2013. Effect of HRT on hydrogen production and organic matter solubilization in acidogenic anaerobic digestion of OFMSW. Chem. Eng. J. 219, 443-449. https://doi.org/10.1016/j.cej.2012.12.090

Sambo, A.S., Garba, B., Danshehu, B.G., 1995. Effect of some operating parameters on biogas production rate. Renew. Energy 6, 343-344. https://doi.org/10.1016/09601481(95)00027-H

Scarlat, N., Dallemand, J.F., Fahl, F., 2018. Biogas: Developments and perspectives in Europe. Renew. Energy 129, 457-472. https://doi.org/10.1016/j.renene.2018.03.006

Schmit, K.H., Ellis, T.G., 2001. Comparison of Temperature-Phased and Two-Phase Anaerobic Co-Digestion of Primary Sludge and Municipal Solid Waste. Water Environ. Res. 73, 314-321. https://doi.org/10.2175/106143001x139335

Soomro, A.F., Abbasi, I.A., Ni, Z., Ying, L., Liu, J., 2020. Influence of temperature on enhancement of volatile fatty acids fermentation from organic fraction of municipal solid waste: Synergism between food and paper components. Bioresour. Technol. 304, 122980. https://doi.org/10.1016/j.biortech.2020.122980

Teixeira Franco, R., Buffière, P., Bayard, R., 2017. Cattle manure for biogas production. Does ensiling and wheat straw addition enhance preservation of biomass and $\begin{array}{llll}\text { methane } & \text { potential? } & \text { Biofuels } & 0,\end{array}$ https://doi.org/10.1080/17597269.2017.1387751 
Teixeira Franco, R., Buffière, P., Bayard, R., 2016. Ensiling for biogas production: Critical parameters. A review. Biomass and Bioenergy 94, 94-104. https://doi.org/10.1016/j.biombioe.2016.08.014

Watts, S., Hamilton, G., Keller, J., 2006. Two-stage thermophilic-mesophilic anaerobic digestion of waste activated sludge from a biological nutrient removal plant. Water Sci. Technol. 53, 149-157. https://doi.org/10.2166/wst.2006.245

Wu, L.J., Kobayashi, T., Li, Y.Y., Xu, K.Q., 2015. Comparison of single-stage and temperature-phased two-stage anaerobic digestion of oily food waste. Energy Convers. Manag. 106, 1174-1182. https://doi.org/10.1016/j.enconman.2015.10.059

Xiao, B., Qin, Y., Zhang, W., Wu, J., Qiang, H., Liu, J., Li, Y.Y., 2018. Temperaturephased anaerobic digestion of food waste: A comparison with single-stage digestions based on performance and energy balance. Bioresour. Technol. 249, 826-834. https://doi.org/10.1016/j.biortech.2017.10.084

Zhang, C., Su, H., Baeyens, J., Tan, T., 2014. Reviewing the anaerobic digestion of food waste for biogas production. Renew. Sustain. Energy Rev. 38, 383-392. https://doi.org/10.1016/j.rser.2014.05.038 
Supplementary Materials for:

Temperature Phased Anaerobic Digestion (TPAD) of Organic Fraction of Municipal Solid Waste (OFMSW) and Digested Sludge (DS): effect of different hydrolysis conditions

\section{Corrado Amodeo $^{1 *}$, Stephane Hattou ${ }^{2}$, Pierre Buffiere ${ }^{1}$, Hassen Benbelkacem ${ }^{1}$}

${ }^{1}$ Univ Lyon, INSA Lyon, DEEP, EA7429, 69621 Villeurbanne, France

${ }^{2}$ Arkolia Energies, 16 Rue des vergers, F34130 Mudaison, France

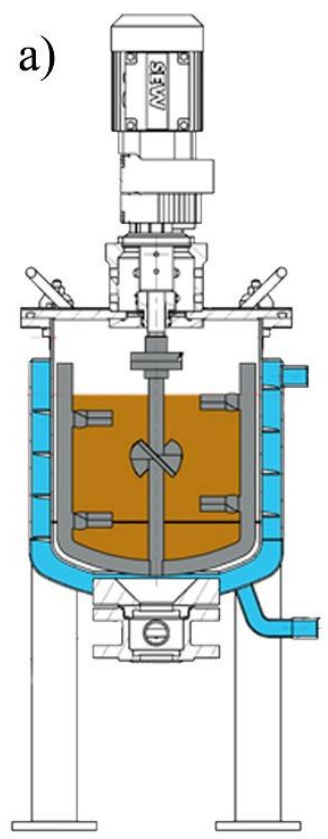

b)

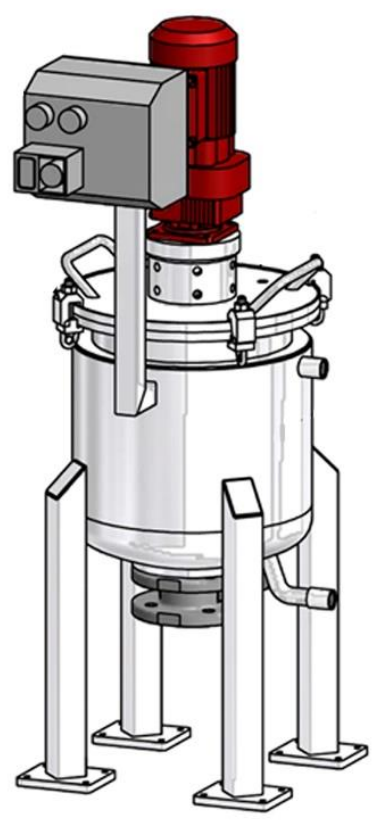

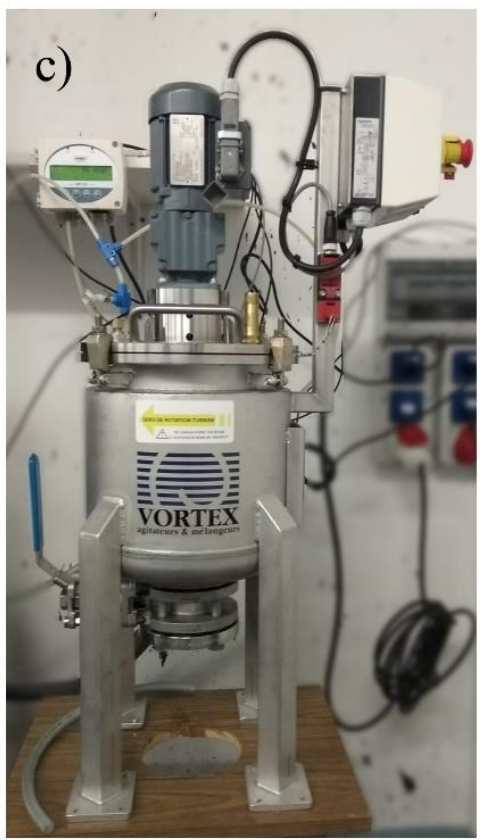

Figure S3 - Hydrolytic reactor: a) Vertical section b) 3D design c) Picture. 
Table S1. Co-digestion mixtures characterization. The concentrations are expressed by mass of raw materials (RM).

\begin{tabular}{cccccccc}
\hline Exp. & $\mathrm{T}$ & $\mathrm{TS}[\%]$ & $\mathrm{VS}[\%]$ & $\begin{array}{c}\mathrm{CODs} \\
{[\mathrm{g} / \mathrm{kgRM}]}\end{array}$ & $\mathrm{pH}$ & $\begin{array}{c}\mathrm{BMP} \\
{\left[\mathrm{mLCH}_{4} \cdot \mathrm{gVs}^{-1}\right]}\end{array}$ & $\begin{array}{c}\mathrm{VFA} \\
{[\mathrm{g} / \mathrm{kgRM}]}\end{array}$ \\
\hline 1 & $37^{\circ} \mathrm{C}$ & 15.4 & 12.4 & 24 & 7.5 & $206 \pm 5$ & 7.6 \\
2 & $55^{\circ} \mathrm{C}$ & 21.3 & 15 & 38 & 7.36 & $237 \pm 5$ & 10 \\
3 & $65^{\circ} \mathrm{C}$ & 20.4 & 14.5 & 32 & 7.36 & $242 \pm 6$ & 10.3 \\
4 & $55^{\circ} \mathrm{C}$ & 24.7 & 15.8 & 58 & 7.05 & $214 \pm 3$ & 19.1 \\
5 & $55^{\circ} \mathrm{C}$ & 23.4 & 14.6 & 29 & 7.58 & $210 \pm 11$ & 7.61 \\
\hline
\end{tabular}

Table S2. Contribution of the soluble fraction on the total BMP.

\begin{tabular}{|c|c|c|c|c|c|c|}
\hline & Experiment & Temp. & $\mathrm{t}_{0}$ & $t_{24}$ & $\mathrm{t}_{48}$ & $\mathrm{t}_{72}$ \\
\hline 1 & $\begin{array}{c}\text { OFMSW_2 } \\
D S \_2\end{array}$ & $37^{\circ} \mathrm{C}$ & $21.8 \%$ & $27 \%$ & $33.7 \%$ & $30.6 \%$ \\
\hline 2 & $\begin{array}{c}O F M S W \_2+ \\
D S \_2\end{array}$ & $55^{\circ} \mathrm{C}$ & $27.1 \%$ & $34.9 \%$ & $33.1 \%$ & $28.2 \%$ \\
\hline 3 & $\begin{array}{c}\text { OFMSW_2 } \\
D S \_2\end{array}$ & $65^{\circ} \mathrm{C}$ & $23.5 \%$ & $32.1 \%$ & $32.9 \%$ & $31.1 \%$ \\
\hline 4 & $\begin{array}{c}\text { OFMSW_l } \\
D S_{-} \_\end{array}$ & $55^{\circ} \mathrm{C}$ & $28.5 \%$ & $40.7 \%$ & $39.7 \%$ & $36.8 \%$ \\
\hline 5 & $\begin{array}{c}\text { OFMSW_2 + } \\
D S \_1\end{array}$ & $55^{\circ} \mathrm{C}$ & $29.2 \%$ & $35.2 \%$ & $35.7 \%$ & $38.3 \%$ \\
\hline
\end{tabular}

